\title{
REKONSTRUKSI LAPORAN KEUANGAN BERBASIS STANDAR AKUNTANSI KEUANGAN ENTITAS MIKRO, KECIL DAN MENENGAH
}

\author{
Atika Dwi Lestari $^{1}$, Yulinartati ${ }^{2}$, Elok Fitriya ${ }^{3}$ \\ ${ }^{1,2,3}$ Program Studi Akuntansi Fakultas Ekonomi dan Bisnis \\ Universitas Muhammadiyah Jember \\ e-mail: atikadl01@gmail.com
}

\begin{abstract}
Abstrak
Standar Akuntansi Keuangan Mikro, Kecil dan Menengah (SAK EMKM) adalah salah satu standar yang dibuat dengan cara sederhana untuk memfasilitasi UMKM untuk menyusun dan menyajikan laporan keuangan bisnis mereka. Penelitian ini menggunakan metode kualitatif dengan metode studi kasus. Jenis data yang digunakan adalah data primer dan data sekunder dengan teknik pengumpulan data observasi, wawancara dan dokumentasi. Hasil penelitian ini menunjukkan bahwa pencatatan dan penyusunan laporan keuangan UD. Kiki Jaya Jember tidak sesuai dengan Standar Akuntansi Keuangan untuk Usaha Mikro, Kecil dan Menengah (SAK EMKM) karena laporan keuangan yang disusun masih sangat sederhana, yaitu hanya mencatat standar penjualan dan pembelian. Setelah direkonstruksi, aplikasi laporan keuangan diproduksi sesuai dengan SAK EMKM yang terdiri dari laporan posisi keuangan, laporan laba rugi dan catatan atas laporan keuangan.
\end{abstract}

Kata kunci : Rekonstruksi, SAK EMKM, UMKM

\begin{abstract}
Micro, Small and Medium Entity Financial Accounting Standards (SAK EMKM) is one standard that is made in a simple way to facilitate MSMEs to compile and present their business financial statements. This study uses qualitative methods with a case study method. The type of data used is primary data and secondary data with observation data collection techniques, interviews and documentation. The results of this study indicate that the recording and preparation of UD financial statements. Kiki Jaya Jember is not in accordance with the Financial Accounting Standards for Micro, Small and Medium Enterprises (SAK EMKM) because the financial statements prepared are still very simple, namely only recording standard sales and purchases. After being reconstructed, the application of financial statements is produced in accordance with the EMKM GAAP which consists of statements of financial position, income statement and notes to financial statements.
\end{abstract}

Keywords : Reconstruction, SAK EMKM, MSMEs 


\section{PENDAHULUAN}

Pemerintah Indonesia terus melakukan pembangunan ekonomi yang bertujuan untuk mensejahterakan rakyatnya. Salah satu usahanya yaitu dengan pembinaan dan menumbuhkembangkan Usaha Mikro Kecil Menengah atau UMKM. Partisipasi dan peran masyarakat adalah indikator yang tinggi dalam pengembangan perekonomian negara.Usaha Mikro Kecil Menengah atau yang sering kita sebut UMKM merupakan salah satu aspek penggerak perekonomian bangsa indonesia. UMKM memiliki peran yang sangat penting, tidak hanya dalam pertumbuhan ekonomi namun juga dalam penyerapan tenaga kerja di Indonesia. Hal tersebut sesuai dengan Undang-Undang Nomor 20 Tahun 2008 Pasal 3 yang menyatakan bahwa "usaha mikro kecil menengah bertujuan untuk menumbuhkan dan mengembangkan usahanya dalam rangka membangun perekonomian nasional berdasarkan demokrasi ekonomi yang berkeadilan".

Dalam perekonomian terutama dalam dunia bisnis salah satu yang menjadi aspek penting bagi kelangsungan usaha yaitu pengelolaan keuangan perusahaan. Dalam menjalankan aktivitas usahanya, namun seringkali UMKM merasa keusulitan melakukan pencatatan yang terjadi dalam operasional usahanya (Sonny, 2010). Adapun kendala yang banyak dihadapi UMKM dalam melakukan pencatatan keuangannya yaitu : (1) latar belakang pendidikan (2) pemahaman teknologi informasi (3) ketidakpahaman tentang penyusunan laporan keuangan. Dalam skala usaha kecil menengah, usaha dikatakan bagus ketika pendapatan sekarang lebih besar dibandingkan pendapatan sebelumnya. Padahal indikator keberhasilan tidak hanya diukur dari aspek pendapatan saja, melainkan perlu adanya pengelompokan dan pengukuran kegiatan atau transaksi serta pengikhtisaran transaksi-transaksi operasional perusahaan.

Ada banyak UMKM yang didirikan di Indonesia termasuk didaerah Jember, salah satunya UMKM UD. Kiki Jaya.UMKM UD. Kiki Jaya merupakan perusahaan manufaktur makanan ringan yaitu mie lidi yang beralamat di Jalan Imam, Lingk. Karang Mluwo, RT.001 RW.008 Kel. Mangli, Kec. Kaliwates, Kabupaten Jember. Dalam penjualannya produk-produk UMKM UD. Kiki Jaya ini tidak hanya dipasarkan di kota Jember saja melainkan ke seluruh kota di pulau Jawa dan di luar pulau jawa seperti Sulawesi dan Papua. Berdasarkan informasi yang penulis dapatkan dari pemilik usaha, pendapatan bersih perbulannya mencapai kurang lebih Rp. 15.000.000 akan tetapi terkait dengan pengelolaan keuangan perusahaan, pemilik mengatakan bahwa kesulitan dalam membuat laporan keuangan karena ketidak pahaman mengenai akuntansi. Selama berdirinya perusahaan sampai saat ini perusahaan hanya menggunakan nota pembelian dan penjualan saja, sehingga informasi yang dihasilkan hanya tentang informasi pembelian bahan dan penjualan saja.

Semakin pesatnya perkembangan suatu usaha maka untuk pendanaan usaha perlu berhubungan dengan pihak luar seperti Bank atau lembaga keuangan lainnya. Untuk itu biasanya Bank dan lembaga keuangan lainnya mensyaratkan laporan keuangan untuk melihat posisi keuangan dan kinerja perusahaan. Karna informasi laporan keuangan sangat dibutuhkan oleh investor untuk menganalisis serta mengambil sebuah keputusan.

Ikatan Akuntan Indonesia (IAI) berusaha memberikan kontribusi untuk mengatasi masalah UMKM dalam penyusunan laporan keuagannya dengan menerbitkan Standar Akuntansi Keuangan Entitas Mikro Kecil Menengah (SAK EMKM) yang telah berlaku efektif mulai 1 Januari 2018. SAK EMKM disusun sangat sederhana untuk mempermudah entitas dalam mengimplementasikannya. Komponen laporan keuangan SAK EMKM terdiri dari neraca, laporan laba rugi dan catatan atas laporan keuangan.

Terdapat beberapa penelitian terdahulu terkait dengan implementasi SAK ETAP atau SAK EMKM. Dedi (2018) dalam penelitiannya yang berjudul "Rancangan Penerapan Standar Akuntansi Keuangan (SAK) Entitas Mikro Kecil Menengah (EMKM) Pada Usaha Mikro Kecil Dan Menengah (UMKM) So Kressh di Kecamatan Blimbing Kota Malang" menyatakan bahwa kesulitan yang ada pada UMKM "So Kressh" karena faktor sumber daya manusia yang kurang mumpuni dalam mengolah keuangan yang sesuai dengan SAK serta ketidaktahuan wawasan pembaharuan tentang standar yang terupdate. Ningtyas (2017) dalam penelitiannya yang berjudul "Penyusunan Laporan Keuangan UMKM Berdasarkan Standar Akuntansi Keuangan Entitas Mikro, Kecil dan Menengah (SAKEMKM) (Study kasus di UMKM Bintang Malam)" menyatakan bahwa dalam penelitiannya di UMKM Bintang Malam pengelolaan keuangan perusahaan, pemilik mengaku kesulitan dalam membuat laporan keuangan yang sesuai standar yang berlaku diindonesia karna dalam perusahaan hanya 
menggunakan nota yang dibukukan. Amani (2018) dalam penelitiannya yang berjudul "Penerapan SAK-EMKM Sebagai Dasar Penyusunan Laporan Keuangan UMKM (studi kasusu di UD Putri Solehah Probolinggo) mengungkapkan bahwa pencatatan laporan keuangan UMKM UD Dua Putri Solehah dilakukan hanya memakai nota penjualan dan pembelian bahan yang masih sederhana. Pemilik mengaku bahwa membutuhkan laporan keuangan yang sesuai dengan standar yang berlaku karena pemilik memiliki cita-cita yang besar untuk mengembangkn usahanya. Berdasarkan hasil penelitian sebelumnya disimpulkan bahwa UMKM tersebut kesulitan untuk membuat laporan keuangan berdasarkan standar yang berlaku di Indonesia, karena faktor sumber daya manusia yang memadai, serta kurangnya pemahaman tentang pembaharuan standar yang terbaru.

Dari latar belakang yang telah di uraikan di atas, untuk itu peneliti tertarik melakukan penelitian tentang Standar Akuntansi Keuangan Entitas Mikro Kecil Menengah atau SAK EMKM dengan judul "REKONSTRUKSI LAPORAN KEUANGAN BERBASIS STANDAR AKUNTANSI KEUANGAN ENTITAS MIKRO, KECIL DAN MENENGAH (Studi Kasus pada UD. Kiki Jaya Jember)".

a) Rumusan Masalah

1. Bagaimana pencatatan dan penyusunan laporan keuangan yang dilakukan oleh UD. Kiki Jaya?

2. Apakah pencatatan dan penyusunan laporan keuangan UD. Kiki Jaya telah sesuai dengan Standar Akuntansi Keuangan Entitas Mikro Kecil dan Menengah (SAK EMKM)?

b) Tujuan

1. Untuk mengetahui pencatatan dan penyusunan laporan keuangan yang dilakukan oleh UD. Kiki Jaya.

2. Untuk mengetahui kesesuaian pencatatan dan penyusunan laporan keuangan UD. Kiki Jaya dengan Standar Akuntansi Keuangan Entitas Mikro Kecil Menengah (SAK EMKM).

c) Manfaat

1. Bagi Perusahaan

Peneliti berharap dapat membantu UMKM UD. Kiki Jaya dalam menyajikan laporan keuangan berdasarkan standar yang berlaku yaitu Standar Akuntansi Keuangan Entitas Mikro Kecil Menengah (SAK EMKM). Sehingga setelah penelitian ini UD. Kiki Jaya mampu menyusun laporan keuangan perusahaannya.

\section{Bagi pembaca}

Melalui penelitian ini penulis berharap dapat menambah wawasan pembaca mengenai laporan keuangan UMKM dan dapat dijadikan sebagai referensi sesuai kebutuhan pembaca.

\section{Bagi penulis}

Hasil penelitian ini di harapkan dapat meningkatkan wawasan penulis dalam hal pengimplementasian SAK EMKM dan juga sebagai pembanding antara teori yang di peroleh dari referensi dan dalam bangku perkuliahan dengan studi kasus di lapangan.

Dalam Undang-Undang No 20 Tahun 2008 menyatakan kriteria UMKM sebagai berikut :Usaha Mikro adalah usaha produktif milik perorangan atau badan usaha yang memenuhi kriteria Usaha Mikro memiliki kekayaan bersih paling banyak Rp50.000.000 (lima puluh juta rupiah) tidak termasuk tanah dan bangunan tempat usaha; atau memiliki hasil penjualan tahunan paling banyak Rp300.000.000 (tiga ratus juta rupiah). Usaha Kecil adalah usaha ekonomi produktif yang berdiri sendiri, yang dilakukan oleh perorangan atau badan usaha yang bukan merupakan anak perusahaan atau bukan cabang perusahaan yang dimiliki, dikuasai, atau menjadi bagian baik langsung maupun tidak langsung dari Usaha Menengah atau Usaha Besar yang memenuhi kriteria Usaha Kecil memiliki kekayaan bersih lebih dari Rp50.000.000 (lima puluh juta rupiah) sampai dengan paling banyak Rp500.000.000 (lima ratus juta rupiah) tidak termasuk tanah dan bangunan tempat usaha;atau memiliki hasil penjualan tahunan lebih dari Rp300.000.000 (tiga ratus juta rupiah) sampai dengan paling banyak Rp2.500.000.000 (dua milyar lima ratus juta rupiah). Usaha Menengah adalah usaha ekonomi produktif yang berdiri sendiri, yang dilakukan oleh perorangan atau badan usaha yang bukan merupakan anak atau cabang perusahaan yang dikuasai, dimiliki, atau menjadi bagian baik langsung ataupun tidak langsung dengan skala Usaha Kecil atau Usaha Besar dengan jumlah kekayaan bersih lebih dari Rp500.000.000 (lima ratus juta rupiah) sampai dengan paling banyak Rp10.000.000.000 (sepuluh milyar rupiah) tidak termasuk tanah dan bangunan tempat usaha atau hasil penjualan tahunan lebih dari Rp2.500.000.000,00 (dua milyar lima ratus juta rupiah) sampai dengan paling banyak Rp50.000.000.000 (lima puluh milyar rupiah). 


\section{Laporan Keuangan}

Laporan keuangan untuk tujuan umum adalah laporan keuangan yang ditujukan untuk memenuhi kebutuhan bersama sebagian besar pengguna laporan keuangan. Laporan keungan untuk tujuan umum termasuk juga laporan keuangan yang disajikan secara terpisah atau yang disajikan dalam dokumen publik lainnya seperti laporan tahunan atau prospektus. Pernyataan ini berlaku pula untuk laporan keuangan konsolidasian (PSAK, 2007: 1.1). Jadi laporan keuangan merupakan suatu penyajian yang sudah dalam keadaan disusun dan diatur rapi dari posisi keuangan dan kinerja keuangan suatu perusahaan. Laporan keuangan meliputi perincian yang menggambarkan posisi keuangan hasil usaha entitas dalam satu periode waktu tertentu.

\section{Standar Akuntansi Keuangan Entitas Mikro Kecil dan Menengah (SAK EMKM)}

Entitas mikro, kecil, dan menengah adalah entitas tanpa akuntabilitas publik yang signifikan atau yang dijadikan anutan, sebagaimana didefinisikan dalam Standar Akuntansi Keuangan Entitas Tanpa Akuntabilitas Publik (SAK ETAP), yang memenuhi definisi dan kriteria usaha mikro, kecil, dan menengah sebagaimana diatur dalam peraturan perundang-undangan yang berlaku di Indonesia, setidaknya selama dua tahun berturut-turut. Menurut IAI dalam SAK EMKM, laporan keuangan entitas mikro kecil menengah yang lengkap terdiri dari laporan posisi keuangan (neraca), laporan laba rugi, dan laporan atas laporan keuangan.

\section{METODE}

Jenis penelitian yang digunakan dalam penelitian ini adalah penelitian deskriptif kualitatif dengan metode studi kasus. Deskriptif kualitatif merupakan data yang berbentuk kata/lisan dari orang atau pelaku yang ditelitiyang bertujuan untuk menggambarkan sesuatu yang tengah berlangsung pada saat studi. Prasetyawan (2018) menjelaskan bahwa penelitian kualitatif ini dilakukan untuk mengamati fenomenafenomena yang ada di objek penelitian lalu menjelaskannya dengan mengembangkan konsep dan menghimpun fakta dari objek tersebut. Penelitian kualitatif tidak melakukan pengujian hipotesis seperti penelitian lainnya. Hamidi dalam Setyawan (2018) menyatakan informan dan responden sebagai subjek penelitian, menjelaskan bahwa yang menjadi pelaku pemberi informasi dalam suatu penelitian adalah mereka, yakni individu atau yang menjadi sumber untuk pengumpulan informasi atau data. Sebuah kegiatan yang dilakukan seorang atau sekelompok orang dalam pandangan peneliti bisa diktakan sebagai subyek penelitian. Maka subyek penelitian dalam penelitian ini adalah UMKM "UD. Kiki Jaya" yang terletak di Jalan Imam, Lingk. Karang Mluwo, RT.001 RW.008 Kel. Mangli, Kecamatan Kaliwates, Kabupaten Jember.

Secara umum jenis data terbagi menjadi dua yaitu data primer dan data sekunder. Dalam penelitian ini peneliti menggunakan dua jenis data sebagai berikut:

1. Data primer

Data primer adalah data yang dikumpulkan, diolah dan disajikan oleh peneliti atau dengan kata lain data primer adalah data yang diperoleh secara langsung dari sumbernya atau tempat penelitian. Peneliti menggunakan data primer ini untuk mendapatkan informasi secara langsung atau wawancara kepada informan sekaligus owner UMKM UD. Kiki Jaya yaitu bapak Mohamad Yulik terkait dengan implementasi SAK EMKM pada usahanya.

\section{Data sekunder}

Data sekunder adalah data yang dikumpulkan, diolah dan disajikan oleh pihak lain, seperti jurnal, laporan keuangan, buku harian, nota, dokumen-dokumen resmi dari instansi pemerintah atau dalam bentuk publikasi lainnya. Peneliti menggunakan data sekunder ini untuk melengkapi informasi dan memperkuat penemuannya yang telah dikumpulkan melalui wawancara langsung kepada owner UMKM UD. Kiki Jaya.

Sanusi dalam Prasetiawan (2018) menyatkan bahwa pengumpulan data yang dapat dilakukan dengan beberapa cara seperti survei, observasi dan dokumentsi. Teknik pengumpulan data berisi cara-cara atau metode yang dilkukan oleh peneliti untuk memperoleh data. Adapun teknik dalam penelitian ini sebagai berikut:

1. Observasi

Creswell dalam Yunita (2018:31) mengatakan bahwa observasi adalah metode pengumpulan data dengan cara peneliti terjun langsung ke lapangan untuk mengmati aktivitas opersional perusahaan. Maka dari itu teknik pengumpulan data melalui observasi ini sangat mendukung dalam penelitian untuk mengetahui kondisi perusahaan secara langsung.

2. Wawancara

Wawancara merupakan teknik pengumpulan data dengn cara tanya jawab secara lisan kepada informan atau subjek yang diteliti. Dalam penelitian ini, teknik 
wawancara yang dilakukan lebih bersifat personal antara peneliti dan subjek atau informan. Hal ini dilakukan peneliti agar data dan informasi yang di dapat dari informan merupakan informasi yang sesungguhnya tanpa adanya kesempatan bagi subjek untuk memanipulasinya. Sehingga data yang di peroleh peneliti merupakan data atau informasi yang akurat.

\section{Dokumentasi}

Dokumentasi merupakan teknik untuk mengumpulkan data dari berbagai sumber baik pribadi maupun kelembagaan serta melihat atau menganalisis dokumen-dokumen yang akan di teliti untuk memastikan kesesuaian atau kebenaran informasi yang diperoleh dari wawancara. Dalam penelitian ini peneliti menggunakan teknik dokumentasi untuk mendapatkan data-data yang nantinya bisa diolah untuk menyelesaikan masalah penelitian. Adapun data yang di maksud berupa catatan dan nota-nota operasional UMKM UD. Kiki Jaya.

Sugiyono (2014) menyatakan bahwa analisis data merupakan proses mencari dan menyusun secara teratur data yang diperoleh dari hasil observasi, wawancara catatan pada saat dilapangan, dan dokumentasi. Dengan cara mengelompokkan data ke dalam kategori, menjabarkan ke dalam unit-unit, menyusun ke dalam pola, memilih yang dibutuhkan dan yang akan di pelajari, serta membuat kesimpulan sehingga mudah dipahami oleh diri sendiri dan orang lain.

Berikut adalah langkah-langkah analisis dalam penelitian ini:

1. Mendeskripsikan pencatatan keuangan UMKM UD. Kiki Jaya yang telah dilakukan sampai saat ini.

2. Mengidentifikasi aktivitas keuangan UMKM UD. Kiki Jaya. Adapun yang dimaksud aktivitas keuangannya mulai dari pembelian bahan baku, hingga proses penjualan sampai perhitungan gaji dan laba perusahaan serta transaksi lainnya yang menunjang perusahaan.

Merekonstruksi laporan keuangan UMKM UD. Kiki Jaya yang sesuai dengan SAK EMKM. Adapun laporan lengkap SAK EMKM seperti: Laporan posisi keuangan, laporan laba rugi, dan catatan atas laporan keuangan.

\section{HASIL DAN PEMBAHASAN}

Laporan keuangan adalah hasil akhir dari proses akuntansi. Laporan keuangan ini mengikhtisarkan data-data transaksi dalam suatu periode akuntansi dalam bentuk yang berguna untuk pengambilan keputusan. Dari hasil wawancara yang telah dilakukan oleh penulis kepada informan yang sekaligus adalah pemilik perusahaan yaitu pak yulik menunjukkan bahwa pemahaman terkait dengan SAK EMKM masih sangat rendah, dikarenakan kurangnya sosialisasi terkait SAK EMKM.

UD. Kiki Jaya adalah sebuah perusahaan manufaktur makanan ringan yang berdiri sejak tahun 2012 dan artinya sudah berdiri selama 7 tahun. Namun pencatatan laporan pembukuan yang dilakukan oleh UD. Kiki Jaya masih sangat sederhana dan manual. Pencatatan dilakukan untuk mengetahui pengeluaran seperti membeli bahan baku, bahan penolong, membayar listrik, telepon dan gaji pegawai. Pencatatan dibuat berdasarkan pemahaman pemilik. Sampai saat ini laporan keuangannya masih sangat sederhana dan tidak menggunakan dasar penyusunan sebagai standar keuangan yang berlaku.

Sebelum melakukan penyususnan laporan keuangan berdasarkan standar akuntansi keuangan entitas mikro kecil dan menengah, penulis menganalisis laporan keuangan yang dimiliki UD. Kiki Jaya agar memudahkan penulis dalam menyusun laporan keuangan berdasarkan standar yang berlaku. Langkah yang dilakukan penulis sebagai berikut: 1) Melakukan identifikasi laporan keuangan yang dibuat oleh UD. Kiki Jaya, 2) Mengumpulkan data dan bukti transaksi yang dimiliki UD. Kiki Jaya, 3) Melakukan proses akuntansi meliputi a) Jurnal umum, b) Buku besar, c) Menghitung depresiasi atau penyusutan, d) Neraca saldo, 4) Penyusunan laporan keuangan sesuai dengan SAK EMKM

\section{a. Laporan posisi keuangan}

laporan posisi keuangan mencakup akunakun seperti kas dan setara kas, piutang, persediaan, aset tetap, utang usaha dan ekuitas. Perusahaan menyajikan akun dan bagian dari akun laporan posisi keuangan jika penyajiannya tersebut relevan untuk memahami posisi keuangan perusahaan. Di dalam SAK EMKM tidak menentukan urutan atau format terhadap akun-akun yang disajikan. Perusahaan dapat menyajikan akunakun aset berdasarkan urutan likuiditas dan akun-akun likuiditas berdasarkan jatuh tempo. 
Tabel 1. Laporan Posisi Keuangan

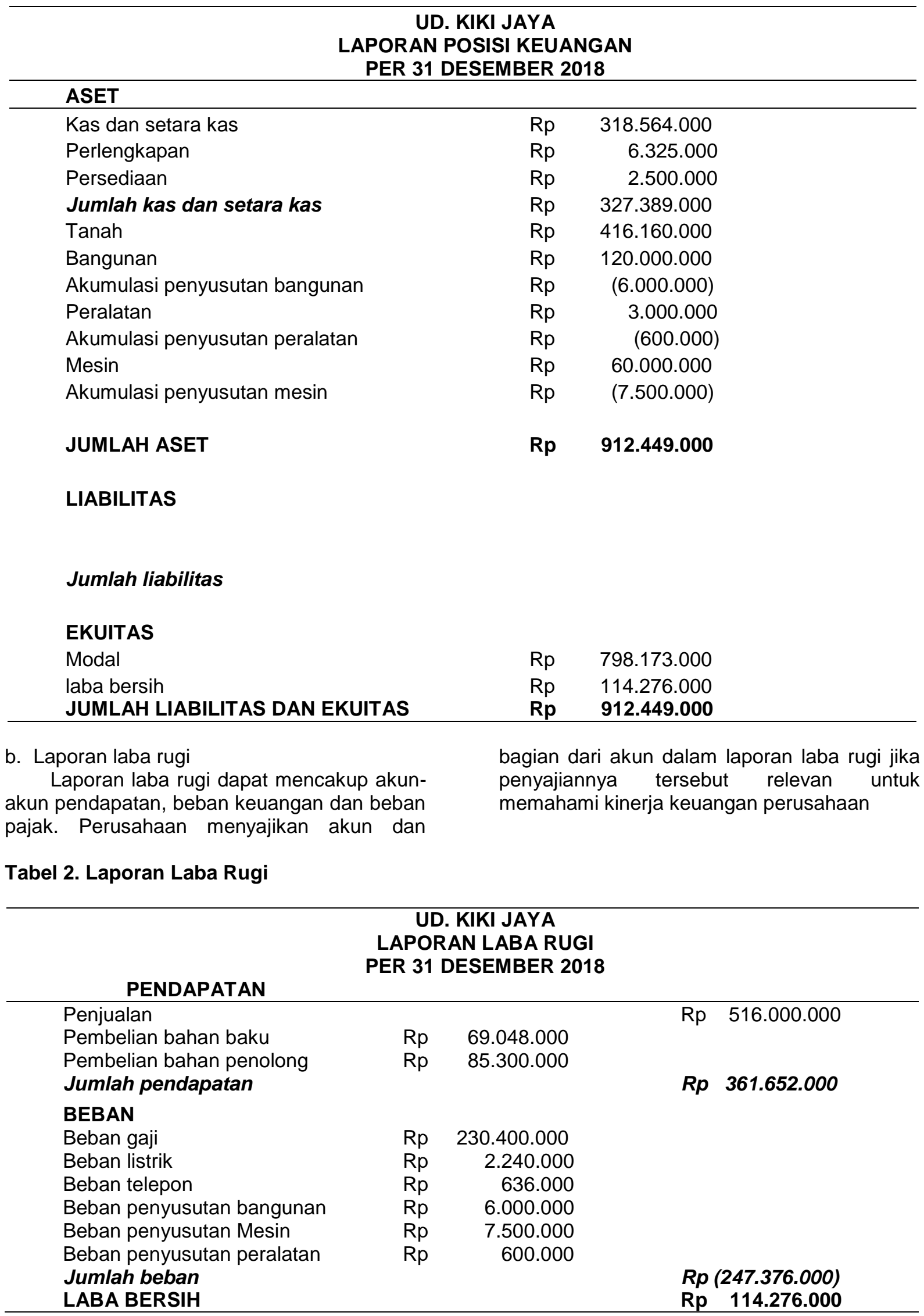


c. Catatan atas laporan keuangan

Catatan atas laporan keuangan ini mendasari informasi yang disajikan dalam catatan atas laporan keuangan dan bagaimana penyajiannya atau dengan kata lain catatan atas laporan keuangan ini memberikan informasi mengenai laporan keuangan bahwa telah disusun berdasarkan SAK EMKM, kebijakan akuntansi, informasi tambahan dan rincian akun-akun tertentu yang menjelaskan transaksi penting. Jenis informasi tambahan dan rincian yang disajikan bergantung pada jenis kegiatan usaha yang dilakukan oleh perusahaan. Catatan atas laporan keuangan disajikan secara teratur sepanjang hal tersebut prktis, setiap akun dalam laporan keuangan merujuk silang ke informasi terkait dalam catatan atas laporan keuangan.

\section{UD. KIKI JAYA \\ CATATAN ATAS LAPORAN KEUANGAN PER 31 DESEMBER 2018}

\section{UMUM}

UD. Kiki Jaya didirikan di kota Jember pada tahun 2012. UD. Kiki Jaya bergerak dibidang usaha manufaktur makanan ringan. UD. Kiki Jaya memenuhi kriteria sebagai entitas mikro kecil dan menengah sesuai dengan UU Nomor 20 Tahun 2008. UD. Kiki Jaya berdomisisli di Jalan Imam, Lingk. Karang Mluwo, RT.001 RW.008 Kel. Mangli, Kecamatan Kaliwates, Kabupaten Jember.

2. IKTISAR KEBIJAKAN AKUNTANSI

a. Pernyataan Kepatuhan

Laporan keuangan disusun berdasarkan Standar Akuntansi Keuangan Entitas Mikro, Kecil dan Menengah.

\section{b. Dasar Penyusunan}

Dasar penyusunan laporan keuangan di UD. Kiki Jaya adalah biaya historis dan menggunakan asumsi dasar akrual. Mata uang penyajian yang digunkan untuk penyusunan laporan keuangan adalah rupiah.

c. Persediaan

Persediaan yang disajikan oleh UD. Kiki Jaya hanya pembelian bahan baku dan bahan penolong.

d. Aset tetap

Aset tetap dalam laporan keuangan dicatat sebesar biaya perolehannya. Aset tetap di susutkan menggunakan metode garis lurus tanpa nilai residu.

e. Pengakuan Pendapatan dan Beban

Pendapatan penjualan diakui pada saat terjadinya penjualan kepada konsumen. Dan beban diakui pada saat terjadinya beban.

3. KAS

Kas

Rp. 318.564.000

\section{SALDO LABA}

Saldo laba merupakan akumulasi selisih pendapatan dan beban setelah dikurangi dengan distribusi pemilik.

\section{PENDAPATAN PENJUALAN}

Penjualan

Rp. 516.000 .000

\section{PENUTUP}

Berdasarkan pembahasan diatas dapat disimpulkan bahwa, pemaham pemilik UD. Kiki Jaya terhadap Standar Akuntansi Keungan Entitas Mikro, Kecil dan Menengah (SAK EMKM) masih sangat minim. Pencatatan dan penyusunan masih sangat sederhana sekali dan sesuai kebutuhan serta pemahman pemilik. Dan artinya UD. Kiki Jaya belum menerapkan pelaporan keuangan sesuai dengan SAK EMKM yaitu laporan posisi keuangan, laporan laba rugi dan catatan atas laporan keuangan. Kendala yang dihadapi oleh entitas dalam menerapkan SAK EMKM yaitu belum adanya tenaga akuntansi pada UD. Kiki Jaya. Pemilik menyadari bahwa pentingnya pencatatan dan penyusunan laporan keuangan untuk keberlangsungan usahanya, akan tetapi belum memahami cara mencatat dan menyusun laporan keuangan yang sesuai standar yang berlaku yaitu SAK EMKM.

Berdasarkan kesimpulan hasil penelitian tersebut, penulis mengajukan saran bagi UMKM UD. Kiki Jaya sebagai berikut: 
UD. Kiki Jaya hendaknya melakukan pencatatan dan penyajian keuangan sesuai dengan standar yang berlaku yaitu SAK EMKM untuk mengelola keuangan serta dapat mengetahui kinerja dan posisi keuangan UD. Kiki Jaya dengan lebih akurat dan juga sebagai dasar pengambilan keputusan ekonomi perusahaan.

UD. Kiki Jaya dalam melakukan pencatatan hendaknya memperhatikan aset perusahaan juga, dan bukan hanya pada pendapatan dan beban. Selain mencatat secara manual, sebaiknya mencatat dan membuat laporan di komputer agar mudah dan hasilnya lebih akurat.

\section{DAFTAR PUSTAKA}

Amani, T. (2018). Penerapan SAK-EMKM Sebagai Dasar Penyusunan Laporan Keuangan UMKM. ASSETS: Jurnal IImiah Ilmu Akuntansi, Keuangan dan Pajak, 2(2), 12-30.

Jusup, H. (2011). Dasar - dasar Akuntansi Jilid 1 Edisi 7. Yogyakarta: Bagian Peneritan Sekolah Tinggi Ilmu Ekonomi YKPN.

Moleong, L. J. (1999). Metodologi penelitian. Bandung: PT. Remaja Rosda Karya.

Muchid, Abdul. 2012. Penyusunan Laporan Keuangan Berdasarkan Standar Akuntansi Keuangan - Entitas Tanpa Akuntabilitas Publik (SAK - ETAP) (Kasus pada UD. Mebel Novel'l di Banyuwangi). Jember: Universitas Jember.

Ningtyas, J. D. A., Si, M., \& Pusmanu, P. (2017). Penyusunan Laporan Keuangan UMKM Berdasarkan Standar Akuntansi Keuangan Entitas Mikro, Kecil dan Menengah (SAK-EMKM)(Study Kasus Di UMKM Bintang Malam Pekalongan). Politeknik Pusmanu.

Prasetiawan, Y. (2015). Rekonstruksi Laporan Keuangan Unit Simpan Pinjam Sesuai SAK ETAP.

Setyawan, D. D. (2018). Rancangan penerapan Standar Akuntansi Keuangan Entitas Mikro Kecil Menengah (SAK EMKM) pada Usaha Mikro Kecil dan Menengah (UMKM)"So Kressh" di Kecamatan Blimbing Kota Malang (Doctoral dissertation, Universitas Islam Negeri Maulana Malik Ibrahim).
Sugiyono. (2014). Metode penelitian kuantitatif, kualitatif dan R\&D. Penerbit alfabeta. Bandung. Undang-undang republik indonesia nomor 20 tahun 2008, usaha mikro kecil menengah.

Yunita, R., \& Mahsun, M. (2018). Evaluasi Penerapan Standar Akuntansi Keuangan Entitas Mikro, Kecil Dan Menengah (Sak Emkm) Pada Laporan Keuangan Koperasi Simpan Pinjam (Ksp) Adil Dlingo (Doctoral dissertation, STIE Widya Wiwaha). 